\title{
Staphylococcus aureus Genotypes of Subclinical Bovine Mastitis Milk in the Middle Western Anatolia
}

\author{
Gülgün Kanber ${ }^{1}$, Beytullah Kenar ${ }^{2}$ and Kıymet Güven ${ }^{3,}$ \\ ${ }^{1}$ Ege University, Graduate School of Science, 35040 Izmir, Turkey \\ ${ }^{2}$ Afyon Kocatepe University, Faculty of Veterinary Medicine, Microbiology, 03200 Afyon, Turkey \\ ${ }^{3}$ Anadolu University, Faculty of Science, Department of Biology, 26470 Eskişehir, Turkey
}

\begin{abstract}
Background: Staphylococcus aureus is the most common etiological pathogen of bovine mastitis. Subclinical mastitis is characterised by a non-alteration of the milk but can cause food poisoning by production of enterotoxins in milk. Knowledge about the genetic variability within different $S$. aureus populations would help in the design of efficient treatments to prevent subclinical mastitis and provide useful data for epidemiological studies. The aim of this study was to characterize the genetic nature of the $S$. aureus cultured from subclinical bovine mastitis occurring in 16 farms in the middle western Anatolia.

Methods: Two hundred sixty eight milk samples positive with California Mastitis Test (CMT) suggesting the subclinical mastitis of lactating cows in 16 different farms in the Middle Western Anatolia were collected and S. aureus were isolated. Identification was carried out by traditional tests and ribotyping confirmed the identification. Staphylococcal Enterotoxins (SE) were detected and typed by Staphylococcal Enterotoxin Test Reversed Passive Latex Agglutination (SET-RPLA) test kit. Genetic characterisation of the isolates was carried out by both ribotyping and pulsed field gel electrophoresis (PFGE).

Results: A total of 77 isolates of $S$. aureus were purified and analysed by both biochemical identification and genotyping. Only 4 isolates $(5.19 \%)$ of $S$. aureus were recorded as enterotoxin positive. Genetic characterisation of the isolates was carried out by ribotyping revealed eight ribotypes while pulsed field gel electrophoresis (PFGE) was more discriminative representing 19 pulsotypes.
\end{abstract}

Conclusion: This study shows no significant association between enterotoxin production, ribogroup and pulsotype profile of the $S$. aureus isolates collected from the Middle Western Anatolia.

Keywords: Bovine subclinical mastitis, Staphylococcus aureus, enterotoxin, genotype.

\section{BACKGROUND}

Mastitis in dairy cows is a worldwide disease and can be caused by infections with bacteria, yeast and fungi [1-4]. However, the most causative microorganisms are bacteria with intramammary infection and there are different bacterial species responsible depending on the geographical location and management. Staphylococcus aureus is a major bacterial pathogen in dairy cattle causing clinical and subclinical mastitis [5-7] and its prevalence ranges from 5 to $50 \%$ in different countries. S. aureus strains can cause acute clinical, and long lasting subclinical mastitis. No alteration is observed in the milk with subclinical mastitis but high somatic cell count is obtained. If the cell count is too high, the milk is inappropriate for the consumers. Halasa et al. [8] reported that this type of mastitis is often chronic and account for up to $30 \%$ of all bovine cases which represents an important economic problem for dairy producers with reduction in milk quantity and quality,

*Address correspondence to this author at the Anadolu University, Faculty of Science, Department of Biology, 26470 Eskişehir, Turkey;

Tel: +90(222)3350580-4724; Fax: +90(222)3353616;

E-mail: kguven@anadolu.edu.tr prolonged costly antibiotic treatments and premature culling. Philpot et al. [9] reported that the reduction in milk production attributed to sub-clinical mastitis may account for $70 \%-80 \%$ of the total losses .

Some $S$. aureus strains have the ability of producing heat stable enterotoxins that cause staphylococcal food poisoning (SFP) [10]. SFP symptoms eg. sickness, abdominal cramps, diarrhoeae and a characteristic projectile emesis [11] appear within a few hours (i.e., 1-6 h) after ingestion of contaminated food, depending on individual susceptibility and toxic dose ingested. The knowledge about the genetic variability within different $S$. aureus populations would help in the design of efficient treatments to prevent subclinical mastitis and provide useful data for epidemiological studies.

The occurrence of mastitis in Turkey has been investigated in many studies and although there are some higher percentages in different regions, mastitis prevalence was reported as $30 \%$ in Turkey $[12,13]$. Many studies focusing on the phenotypic and genotyping characterization of $S$. aureus isolated from subclinical bovine mastitis in different regions of Turkey were carried out by coagulase gene polymorphisms 
detected by PCR [14], determination of classical enterotoxigenic characteristics [15], detection of superantigenic toxin genes [16]), comparing the antibiotic resistance profiles. Ünal and İstanbulluoğlu [17] revealed clonal relations of only a small number of $S$. areus by using Pulsed field gel electrophoresis (PFGE) and a clone of the bacterium was broadly detected in dairy farms in Kırıkkale province. However, there is no study by comparison of different methods about the characterization of strains of $S$. aureus related to subclinical mastitis occurring in farms in the Middle Western Anatolia.

Therefore, the aim of the present study was to detect staphylococcal enterotoxins and determine the genetic profiles of $S$. aureus strains isolated from milk of cows suffering from subclinical mastitis in the Middle
Western Anatolia by using PFGE and automated ribotyping. To our knowledge, ribotyping is the first study revealing riboprofiles of subclinical mastitis causing $S$. aureus in Turkey.

\section{METHODS}

\section{Isolates}

Two hundred sixty eight milk samples positive with California Mastitis Test (CMT) indicating the subclinical mastitis of lactating cows in 16 different farms in the Middle Western Anatolia were collected for microbial evaluation in 2010-2011. Each milk sample was aseptically collected into sterile bottles just before milking and they were transported in a cool box at $4^{\circ} \mathrm{C}$ to the laboratory. The CMT and bacteriological

Table 1: Characterisation of $S$. aureus Isolates

\begin{tabular}{|c|c|c|c|c|c|c|c|c|c|c|c|c|c|c|}
\hline $\begin{array}{c}\text { Isolate } \\
\text { No. }\end{array}$ & Farm & $\begin{array}{l}\text { SET- } \\
\text { RPLA }\end{array}$ & $\begin{array}{l}\text { Ribo- } \\
\text { group }\end{array}$ & $\begin{array}{l}\text { Pulso- } \\
\text { type }\end{array}$ & $\begin{array}{c}\text { Isolate } \\
\text { No. }\end{array}$ & Farm & $\begin{array}{l}\text { SET- } \\
\text { RPLA }\end{array}$ & $\begin{array}{l}\text { Ribo- } \\
\text { group }\end{array}$ & $\begin{array}{l}\text { Pulso- } \\
\text { type }\end{array}$ & $\begin{array}{c}\text { Isolate } \\
\text { No. }\end{array}$ & Farm & $\begin{array}{l}\text { SET- } \\
\text { RPLA }\end{array}$ & $\begin{array}{l}\text { Ribo- } \\
\text { group }\end{array}$ & $\begin{array}{c}\text { Pulso- } \\
\text { type }\end{array}$ \\
\hline 6 & E1 & - & 1 & G1 & 120 & $\mathrm{C} 1$ & - & 3 & G11 & 224 & A3 & - & 7 & G19 \\
\hline 11 & E1 & - & 2 & G1 & 122 & $\mathrm{C} 1$ & C & 5 & G12 & 228 & D1 & - & 4 & G11 \\
\hline 15 & E1 & - & 3 & G2 & 128 & $\mathrm{C} 2$ & - & 7 & G11 & 231 & D1 & - & 7 & G11 \\
\hline 22 & E1 & - & 1 & G1 & 132 & $\mathrm{C} 2$ & - & 7 & G11 & 233 & D1 & - & 3 & G11 \\
\hline 27 & E1 & - & 5 & G4 & 138 & $\mathrm{C} 2$ & - & 8 & G11 & 234 & D1 & - & 5 & G11 \\
\hline 44 & E1 & - & 5 & G15 & 142 & $\mathrm{~A} 1$ & - & 7 & G11 & 240 & D1 & - & 2 & G11 \\
\hline 49 & E1 & - & 7 & G7 & 143 & $\mathrm{~A} 1$ & - & 2 & G11 & 243 & D1 & - & 7 & G11 \\
\hline 56 & E2 & - & 4 & G6 & 163 & $\mathrm{~A} 1$ & - & 2 & G16 & 262 & D2 & - & 1 & G19 \\
\hline 58 & E2 & - & 3 & G11 & 169 & $\mathrm{~A} 1$ & - & 1 & G17 & 264 & D3 & - & 1 & G19 \\
\hline 60 & E2 & - & 4 & G19 & 181 & $\mathrm{~A} 1$ & - & 1 & G19 & 272 & D3 & - & 7 & G11 \\
\hline 84 & E2 & - & 7 & G7 & 185 & $\mathrm{~A} 1$ & - & 3 & G11 & 273 & D3 & - & 1 & G19 \\
\hline 85 & E3 & - & 5 & G11 & 190 & $\mathrm{~A} 2$ & - & 3 & G11 & 274 & D3 & - & 7 & G11 \\
\hline 92 & B1 & - & 7 & G11 & 191 & A2 & - & 3 & G11 & 276 & $\mathrm{~S} 1$ & - & 1 & G19 \\
\hline 94 & B1 & - & 7 & G11 & 193 & $\mathrm{~A} 2$ & - & 3 & G11 & 279 & $\mathrm{~S} 1$ & - & 3 & G19 \\
\hline 96 & B1 & - & 3 & G11 & 194 & $\mathrm{~A} 2$ & - & 3 & G11 & 283 & $\mathrm{~S} 1$ & - & 3 & G19 \\
\hline 118 & $\mathrm{C} 1$ & - & 7 & G11 & 220 & A3 & - & 3 & G11 & & & & & \\
\hline
\end{tabular}


analyses were started within $24 \mathrm{~h}$ after sampling. For isolation of $S$. aureus, $10 \mathrm{ml}$ of milk sample were centrifuged at $6000 \mathrm{rpm}$ for ten minutes and after discarding the supernatant, the sediment were inoculated on Mannitol Salt Agar (MSA) with incubation at $37^{\circ} \mathrm{C}$ for 24 to $48 \mathrm{~h}$ for primary isolation. Suspected colonies were selected and subcultured on blood agar medium for obtaining pure culture. $S$. aureus was identified at the species level using standard biochemical methods including Gram stain, catalase, tube coagulase, oxidase, DNase activities, Growth on Baird Parker medium and fermentation of mannitol [18] and API Staph test (BioMerieux, France). Isolates identified as $S$. aureus by these classical tests were then evaluated for enterotoxin production and genotyping by both automated ribotyping and PFGE (Table 1).

\section{Detection of Staphylococcal Enterotoxins (SE)}

Strains were grown in $10 \mathrm{~mL}$ of tryptone soya broth (CM0219B, Oxoid) for $16-18 \mathrm{~h}$ at $37{ }^{\circ} \mathrm{C}$ by shaking aerobically. After centrifugation, the supernatant was tested for the presence and typing of SEs by Staphylococcal Enterotoxin Test Reversed Passive Latex Agglutination (SET-RPLA) (TD900, Oxoid).

\section{Ribotyping}

Strains identified as $S$. aureus with conventional biochemical tests were then characterized by automated ribotyping using EcoRI in a robotized instrument (Riboprinter ${ }^{\mathrm{TM}}$ Microbial Characterization System, Qualicon, DuPont, Wilmington, DE) and the Riboprinter TM System Data Analysis Program. The procedure used for processing each sample is described in detail by the manufacturer. The identification of each strain was obtained when the corresponding pattern matched one of the pattern of the DuPont Identification library of the Riboprinter ${ }^{\circledR}$ with a similarity $\% 0.86$. The characterisation consisted of combining profiles within a similarity range equal or larger than 0.93 to form a dynamic ribogroup that reflected the genetic relatedness of the strains [19]. Each ribogroup was numbered by the system used in the study. A similarity dendogram was generated based on the banding pattern similarities by using SPSS version 21.0.

\section{Pulsed Field Gel Electrophoresis (PFGE) Analyses}

The genetic relationships of $S$. aureus isolates collected from cows with subclinical mastitis were compared by the DNA macrorestriction patterns obtained from PFGE following Sma I digestion. PFGE typing of strains was performed according to the methods of Vanderlinde [20] and Hennekinne et al. [21] with some modifications. The electrophoresis was carried by using a Chef Mapper (Bio-Rad Laboratories, Hercules, CA) and pulse times were ramped from $5 \mathrm{~s}$ to $40 \mathrm{~s}$ for $19 \mathrm{~h}$. Gels were stained with ethidium bromide, visualized using an ultraviolet transilluminator, and photographed. Strains of $S$. aureus were placed in groups of identical or related strains by comparing the banding patterns produced, using a combination of photographic visiual inspection and computer analysis (SPSS version 21.0, SPSS Inc., Chicago, IL) was carried out to create a similarity dendogram. A pulsotype (PT) was defined as a unique electrophoretic banding pattern. Strains with identical restriction profiles were assigned as the same type.

\section{RESULTS}

\section{Isolation and Identification of S. aureus}

A total of 185 isolates were collected from 463 mastitis positive milk samples and identification was carried out by both conventional biochemical tests and ribotyping. However, only 77 isolates collected from 8 out of 16 different farms were identifed as $S$. aureus by both conventional biochemical tests and ribotyping (Table 1).

\section{Detection of Staphylococcal Enterotoxins}

Using the SET-RPLA test, 73 out of the 77 isolates of the $S$. aureus $(94.8 \%)$ showed no enterotoxin activity, only 4 isolates $(5.19 \%)$ isolated from mastitis positive milk samples were recorded as positive. Three isolates (numbered 101, 115 and 131) synthesized Staphyloccal enterotoxin B however, only one isolate (122) synthesized Staphyloccal enterotoxin C (Table 1). No correlation was obtained between enterotoxin profiles and pulsotypes of the isolates (Table 1).

\section{Ribotyping}

In this study, automated riboprinting was applied to the 77 isolates of $S$. aureus for both confirmation of the classical identification and ribotyping. All the isolates tested were typeable. Restriction of the total DNA with EcoRl yielded about 14 fragments of $1-50 \mathrm{~kb}$ in size. A total of eight banding patterns were obtained among the strains (Figure 1). The most prevalent ribotype was Ribotype 5 represented by 20 isolates (Table 1 ). 


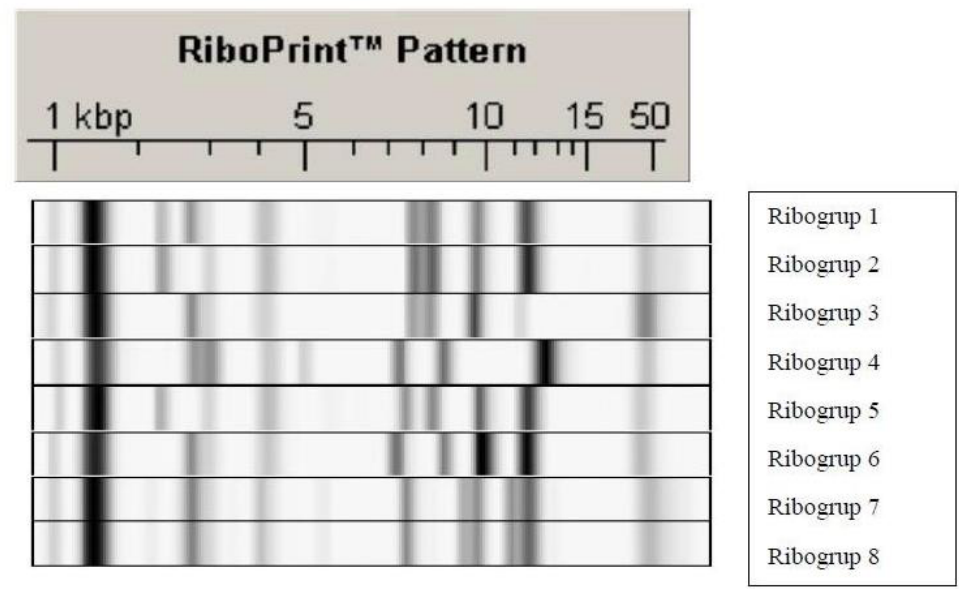

Figure 1: Ribotypes from $S$. aureus isolated from different subclinical mastitis milk samples (ribogroup numbers were given by automatic ribotyping system).

A dendogram based on the similarity was obtained. Ribogroups 7 and 8 showed $98 \%$ similarity while all the ribogroups were clustered in a group with a $95 \%$ similarity (Figure 2). Automated ribotyping was applied for the first time for evaluation of $S$. aureus isolates collected from subclinical mastitis positive milk samples in Turkey. All the farms contained different ribogroups of $S$. aureus except farms E3, B2 and A2. Farms D2 and D3 contained same ribogrous while farms E3, B2 and A2 contained only one ribogroup of $S$. aureus (Table 1).

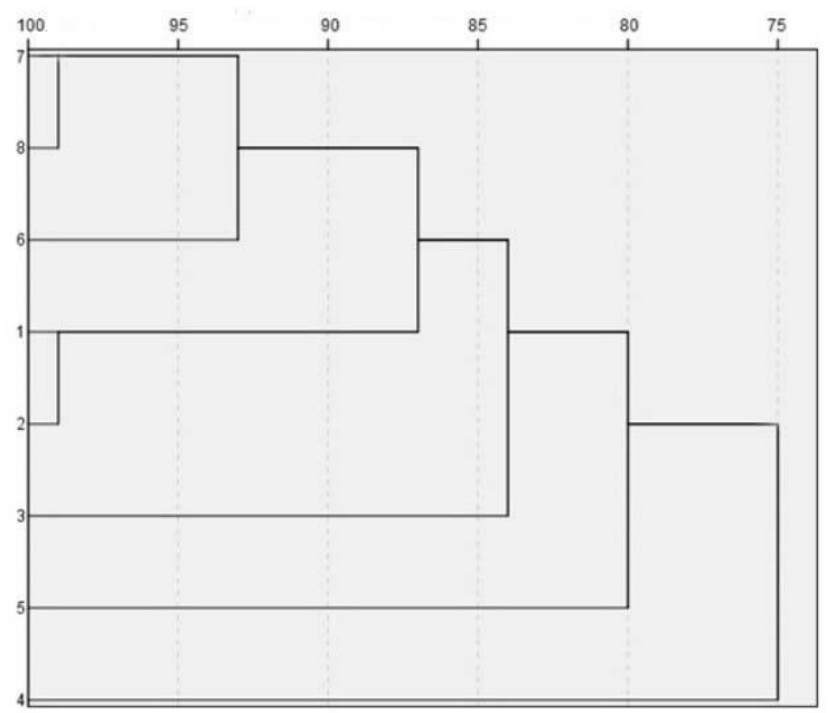

Figure 2: Dendogram constructed on the basis of ribotype patterns of $S$. aureus obtained by Eco RI enzyme.

\section{PFGE Analyses}

All of the isolates tested were typeable with Pulsed Field Gel Electrophoresis (PFGE). The genetic analyses revealed 19 different PTs varying from 17 to
23 distinct bands in the range from $485 \mathrm{~kb}$ to $48.5 \mathrm{~kb}$ indicating high genetic diversity among the samples (Figure 3). Pulsotype G11 contained 38 isolates (49,3\%), pulsotype G19 contained 17 isolates $(22 \%)$, pulsotype $\mathrm{G} 1$ contained 3 isolates (3,8\%), pulsotype G5 contained 3 isolates $(3,8 \%)$, pulsotype G7 contained 2 isolates (2,59\%). Other pulsotypes were represented by only one isolate. 77 isolates collected from 16 different farms were analyzed with PFGE and farms E3, B1, B2, A2 and D1 contained only one pulsotype either $\mathrm{G} 11$ or $\mathrm{G} 19$ indicating that the source of mastitis was same strain of $S$. aureus. However other farms were represented by different pulsotypes as indication of different strains of $S$. aureus caused mastitis (Table 2).

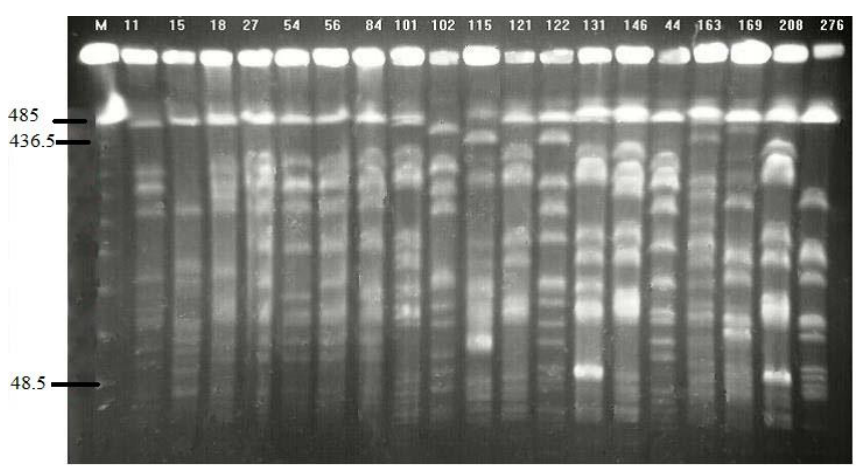

Figure 3: Restriction endonuclease digestion of total genomic DNA of strains representing some of the groups PFGE profiles of staphylococcus aureus after restriction digestion with Smal and separation by PFGE. Lanes show some of the pulsotypes represented in Table 1 and $M, 48.5$ 1,000-kB concatamer ladder (Bio-Rad). The PFGE conditions were $1 \%(\mathrm{w} / \mathrm{v})$ agarose gel in $0.5 \mathrm{X}$ TBE, switching pulses of 5 to $40 \mathrm{~s}$ at a period of $19 \mathrm{~h} 6 \mathrm{~V} / \mathrm{cm}$.

A dendogram that included all patterns was constructed on the basis of the similarity levels. A high 
Table 2: Spread of Pulsotypes in the Farms

\begin{tabular}{|c|c|c|c|c|c|}
\hline Farm & Pulsotype & No. isolates & Farm & Pulsotype & No. isolates \\
\hline E1 & G1,G2,G3,G4,G5,G7,G15,G19 & 10 & $\mathrm{~A} 1$ & G11,G14,G16,G17,G19 & 9 \\
\hline E2 & G5,G6,G7,G11,G19 & 6 & A2 & G11 & 4 \\
\hline E3 & G11 & 1 & A3 & G11,G18,G19 & 7 \\
\hline B1 & G11 & 4 & D1 & G11 & 9 \\
\hline B2 & G19 & 1 & $\mathrm{D} 2$ & G11,G19 & 3 \\
\hline B3 & G8, G9 & 2 & D3 & G11,G19 & 4 \\
\hline $\mathrm{C} 1$ & G10,G11,G12 & 5 & S1 & G11,G19 & 3 \\
\hline $\mathrm{C} 2$ & G11,G13 & 4 & $\mathrm{~S} 2$ & G11,G19 & 5 \\
\hline
\end{tabular}

degree of similarity was observed between the pulsotypes $4-7$ and 5-6. Secondry level of high degree of similarity was observed between pulsotypes 14-18 and 8-11 (Figure 4).

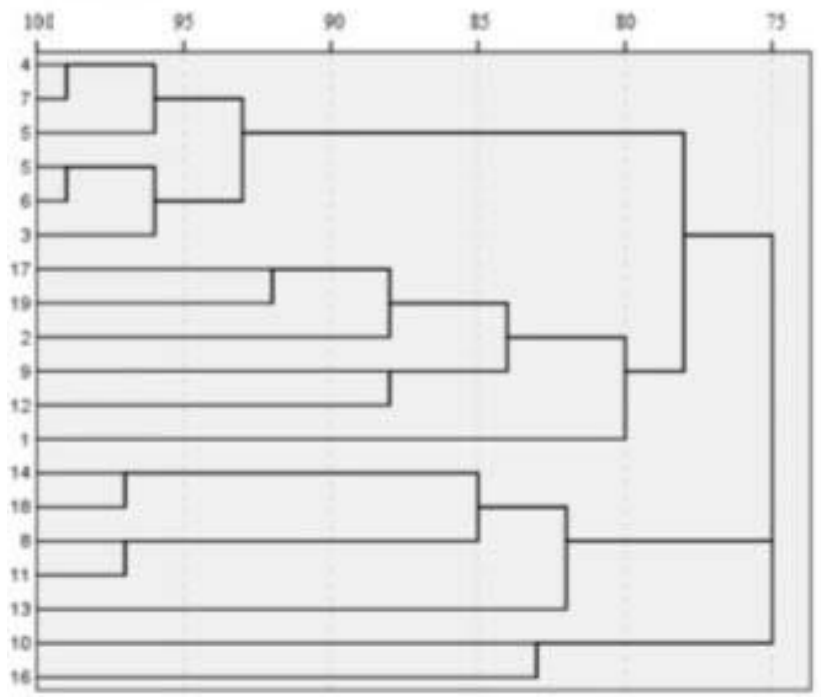

Figure 4: Dendogram constructed on the basis of 19 pulsotype patterns of $S$. aureus strains established with Sma I PFGE analysis. Pulsotype numbers are given in Table 1.

\section{DISCUSSION}

Subclinical mastitis causes elevated somatic cell counts (SCC) but no detectable changes in milk or the udder. The bacteria persist in mammary glands, teat canals, and teat lesions of infected cows and are contagious. Economic damage due to subclinical mastitis has been mainly attributed to the fact that a subclinical cow is a constant source of infection to otber cows and to milk production loss as reported by Swinkels et al. [22]. In this study, only 77 isolates out of 185 were identified as $S$. aureus as a causative organism of subclinical mastitis suggesting that other bacteria were responsible as indicated in Hegde et al.
[23]. S. aureus can access to milk by direct excretion from udders during milking [24] and multiply in milk and produce enterotoxins that cause food poisoning if ingested [25]. Staphylococcal enterotoxins have a remarkable ability to resist heat and denaturation by cooking therefore, even after pasteurization biological activity of toxin remains and can cause food poisoning [26]. A relatively high percentage of classical enterotoxin forming $S$. aureus strains from bovine subclinical mastitis was recorded in many publications [27-29].

Boynukara et al., [15] first investigated classical enterotoxigenic properties of Staphylococcus aureus strains isolated from cows with subclinical mastitis in eastern part of Turkey with $106 \mathrm{~S}$. aureus strains. Twenty seven isolates $(25.5 \%)$ were found to be enterotoxigenic by reverse passive latex agglutination (RPLA). Of these, 25 (23.6\%) were positive for staphylococcal enterotoxin A (SEA), 2 (1.9\%) for staphylococcal enterotoxin B. Their study showed that most $S$. aureus strains isolated from bovine subclinical mastitis produced SEA compared to other SEs. However in this study, the prevelance of SE strains were very low $(5.19 \%)$ being the SEB $(3.89 \%)$ and SEC (1.29\%) among 77 isolates of $S$. aureus.

The present study involved 77 isolates recovered from 16 commercial dairy farmss located in the middle western Anatolia, with different $S$. aureus ribotype and pulsotype prevalence. Although the number of isolates is not too large, it allowed us to develop a small-scale project aimed to assess the relationship between $S$. aureus ribotype and pulsotype pattern and the prevalence of them in dairy farms. Moreover, this study represents, in our knowledge, the first application of ribotyping technique to evaluate the role of $S$. aureus virulence factor patterns in subclinical mastitis prevalence in dairy farms in Turkey. 


\section{CONLUSION}

The strains producing SEs indicates very low potential of poisoning in milk samples collected from subclinical mastitis infected cows in the Middle Western Anatolia. Also, no significant association between enterotoxin production, ribogroup and pulsotype was observed in the current study. Future studies involving biofilm production ability of the isolates as carried out by Khoramrooz et al. [30] may explain a possible correlation between enterotoxin genes with biofilm formation and genotypes.

\section{ACKNOWLEDGEMENTS}

We gratefully thank Erdoğan Çakır for his technical assistance in ribotyping. The article being published represent research outcome that was funded by Anadolu University Research Foundation for financial support through Project number 1109F149.

\section{REFERENCES}

[1] Bradley AJ, Green MJ. Adaptation of Escherichia coli to the Bovine Mammary Gland. J Clin Microbiol 2001; 39: 18451849.

https://doi.org/10.1128/JCM.39.5.1845-1849.2001

[2] Bramley AJ, Dodd FH. Reviews of the progress of dairy science: mastitis control-progress and prospects. J Dairy Res 1984; 51: 481-512. https://doi.org/10.1017/S0022029900023797

[3] Costa EO, Melville A, Ribeiro AR, Watanabe ET, Parolari MCFF. Epidemiologic study of environmental sources in a Prototheca zopfii outbreak of bovine mastitis. Mycopathologia 1997; 137: 33-36. https://doi.org/10.1023/A:1006871213521

[4] Moretti A, Pasquali P, Mencaroni G, Fioretti DP. Relationship Between Cell Counts in Bovine Milk and the Presence of Mastitis Pathogens (Yeasts and Bacteria). J Vet Med B 1998; 45: 129-32.

https://doi.org/10.1111/j.1439-0450.1998.tb00775.x

[5] Piepers SL, De Meulemeester L, De Kruif A, Opsomer G, Barkema HW, De Vliegher S. Prevalence and distributionof mastitis pathogens in subclinically infected dairy cows in Flanders, Belgium. J Dairy Res 2007; 74: 478-483. https://doi.org/10.1017/S0022029907002841

[6] Tenhagen BA, Koster G, Wallmann J. Heuwieser W. Prevalence of mastitis pathogens and their resistance against anti-microbial agents in dairy cows in Brandenburg, Germany. J Dairy Sci 2006; 89: 2542-2551. https://doi.org/10.3168/jds.S0022-0302(06)72330-X

[7] Waage S, Sviland S, Odegaard SA. Identification of risk factors for clinical mastitis in dairy heifers. J Dairy Sci 1998; 81: $1275-1284$

https://doi.org/10.3168/jds.S0022-0302(98)75689-9

[8] Halasa $\mathrm{T}$, Huijps $\mathrm{K}$, Osteras $\mathrm{O}$, Hogeveen $\mathrm{H}$. Economic effects of bovine mastitis and mastitis management: $A$ review. Vet Q 2007; 29: 18-31. https://doi.org/10.1080/01652176.2007.9695224

[9] Philpot WN, Nickerson SC. Mastitis. Napervile, IL: Babson Bros. Co., Publishing; 1991.

[10] Dinges MM, Orwin PM, Schlievert PM. Exotoxins of Staphylococcus aureus. Clin Microbiol Rev 2000; 13: 16-34. https://doi.org/10.1128/CMR.13.1.16-34.2000
Normanno TG, La Salandra G, Dambrosio A, Quaglia NC, Corrente M, Parisi A, Santagada G, Firinu A, Crisetti E, Celano GV. Occurrence, characterization and antimicrobial resistance of enterotoxigenic Staphylococcus aureus isolated from meat and dairy products. Int J Food Microbiol 2007; 115: $290-296$

\section{https://doi.org/10.1016/j.ijfoodmicro.2006.10.049}

[12] Mutluer B. Süt İnekçiliğinde Mastitis Sempozyumu. Akdeniz Üniversitesi Veteriner Fakültesi Yayın Ünitesi.Yayın no: 2; 2001.

[13] Sabuncuoğlu N, Coban Ö. Mastitis Ekonomisi. Atatürk Üniversitesi Veteriner Bilimleri Dergisi 2006; 1: 1-5.

[14] Karahan M, Cetinkaya B. Coagulase gene polymorphisim detected by PCR in Staphylococcus aureus isolated from subclinical bovine mastitis in Turkey. Vet $\mathrm{J} 2007$; 174: 428431.

https://doi.org/10.1016/j.tvjl.2006.05.016

[15] Boynukara B, Gulhan T, Alisarli M, Gurturk K, Solmaz H. Classical enterotoxigenic characteristics of Staphylococcus aureus strains isolated from bovine subclinical mastitis in Van, Turkey. Int J Food Microbiol 2008; 125: 209-211. https://doi.org/10.1016/j.ijfoodmicro.2008.03.024

[16] Günaydin B, Aslantaş Ö, Demir C. Detection of superantigenic toxin genes in Staphylococcus aureus strains from subclinical bovine mastitis. Trop Anim Health Prod 2011; 43: 1633-1637. https://doi.org/10.1007/s11250-011-9882-5

[17] Ünal N, İstanbulluoğlu E. İnsan ve sığır kökenli Staphylococcus aureus izolatlarının fenotipik ve genotipik özelliklerinin araștırılması. Ankara Üniv Veteriner Fakültesi Dergisi 2009; 56: 119-126. https://doi.org/10.1501/Netfak 0000002171

[18] Bisping W, Gunter A. Colour Atlas fort the Diagnosis of Bacterial Pathogens in Animals. Germany: Paul Parey Scientific Publishers Berlin and Hamburg; 1998.

[19] Bruce J. Automated system rapidly identifies and characterises microorganisms in foods. Food Technol 1996; 50: 77-78.

[20] Vanderlinde PB, Fegan N, Mills L, Desmarchelier PM. Use of pulse field gel electrophoresis for the epidemiological characterisation of coagulase positive Staphylococcus isolated from meat workers and beef carcasses. Int J Food Microbiol 1999; 48: 81-85 https://doi.org/10.1016/S0168-1605(99)00032-X

[21] Hennekinne JA, Keouanton A, Brisabois A, De Buyser M.L. Discrimination of Staphylococcus aureus biotypes by pulsedfield gel electrophoresis of DNA macrorestriction fragments. $J$ Appl Microbiol 2003; 94: 321-329. https://doi.org/10.1046/j.1365-2672.2003.01837.x

[22] Swinkels JM, Hogeveen H, Zadoks RN. A partial budget model to estimate economic benefits of lactational treatment of subclinical Staphylococcus aureus mastitis. J Dairy Sci 2005; 88: 4273-4287. https://doi.org/10.3168/jds.S0022-0302(05)73113-1

[23] Hegde R, Isloor S, Prabhu NK, Shome BR, Rathnamma D, Suryanarayana VVS, Yatiraj S, Prasad CR, Krishnaveni N, Sundareshan S, Akhila DS, Gomes AR, Hegde RN. Incidence of Subclinical Mastitis and Prevalence of Major Mastitis Pathogens in Organized Farms and Unorganized Sectors. Indian J Microbiol 2013; 53: 315-320. https://doi.org/10.1007/s12088-012-0336-1

[24] Scherrer D, Corti S, Muehlherr J, Zweifel C, Stephan R. Phenotypic and genotypic characteristics of Staphylococcus aureus isolates from raw bulk tank milk samples of goats and sheep. Vet Microbiol 2004; 101: 101-107. https://doi.org/10.1016/j.vetmic.2004.03.016

[25] Ding T, Yu YY, Schaffner DW, Chen SG, Ye XQ. Farm to consumption risk assessment for Staphylococcus aureus and 
staphylococcal enterotoxins in fluid milk in China. Food Control 2016; 59: 636-643.

https://doi.org/10.1016/j.foodcont.2015.06.049

[26] Rall V, Vieira F, Rall R, Vieitis R, Fernandes A, Candeias J, Cardoso JP, Araújo JR. PCR detection of staphylococcal enterotoxin genes in Staphylococcus aureus strains isolated from raw and pasteurized milk. Vet Microbiol 2008; 132: 408413.

https://doi.org/10.1016/j.vetmic.2008.05.011

[27] Da Silva ER, Do Carmo LS, Da Silva N. Detection of the enterotoxins A, B, and C genes in Staphylococcus aureus from goat and bovine mastitis in Brazilian dairy herds. Vet Microbiol 2005; 106: 103-107. https://doi.org/10.1016/j.vetmic.2004.12.005

[28] Kuzma K, Malinowski E, Lassa H, Klossowska A. Detection of genes for enterotoxins and toxic shock syndrome toxin-1in
Staphylococcus aureus isolated from bovine mastitis. Bull Vet Inst Pulawy 2003; 47: 419-426.

[29] Serraino A, Alberghini L, Fontana MC, Annemüller C, Lämmler C, Rosmini R. Occurrence of enterotoxin genes and macrorestriction analysis of Staphylococcus aureus isolated from bovine mastitis and bulk-tank milk samples in Italy. An epidemiological study. Ital J Anim Sci 2004; 3: 47-53. https://doi.org/10.4081/ijas.2004.47

[30] Khoramrooz SS, Mansouri F, Marashifard M, Hosseini S Chenarestane-Olia FA, Ganavehei B, Gharibpour F, Shahbazi A, Mirzaii M, Darban-Sarokhalil D. Detection of biofilm related genes, classical enterotoxin genes and agr typing among Staphylococcus aureus isolated from bovine with subclinical mastitis in southwest of Iran. Microb Pathog 2016; 97: 45-51.

https://doi.org/10.1016/j.micpath.2016.05.022 